\title{
Time Bank: Exploration on Pattern of Residence for the Aged under Shared Economy
}

\author{
Jie-qian $\mathrm{ZHANG}^{1, a,{ }^{*}}$ \\ ${ }^{1}$ Department of Economics \& Management, Tianjin Agricultural University, \\ 22 Jinjing Road, Xiqing District, Tianjin, China \\ a603669916@qq.com
}

Key words: Shared economy, Pension service, Time Bank.

\begin{abstract}
Time Bank, like traditional banks, is the service institution which supplies to clients stored and withdrawal service of laboring time. New pattern of old-age care can be explored according to the operation of Time Bank. After analyzing difficulties and troubles in the operation of Time Bank, the article came to the conclusion that shared economy made solving the difficulties and troubles possible and gave the idea of building Time Bank under shared economy from three aspects, the analysis of practicability, the building principles and the construction design.
\end{abstract}

\section{Introduction}

As our country is becoming an old-aged one, how to provide for the aged has become a popular problem among Chinese people. Social insurance, business insurance and HECM supply financial support for the lives of the old. And geracomium, community endowment, volunteers, housekeeping give labor service for elders to some extent. But there are lots of problems about pension service waiting to be solved, such as the lack of pension and geracomium and the lack of standard serving people and so on. Currently, it is a common view in our country that we should save money for our aged time at a young age. If there is the possibility to save labor for aged ourselves when we are young and to build up Time Bank which advocates that we serve for our old time ourselves, it is no more than an attempt to new pattern of old-age care.

\section{The Brief Introduction of Time Bank}

Time Bank is the idea which was given by an American, Edcar Carn in 1980. He suggested finding a service institution like banks. Participants store service time into Time Bank which is based on the time you serving others, and get the time for serving from banks when they need service and help. The idea is similar with the concept advised by a civilized society-'do the service today, and you can enjoy the serving tomorrow'. Because of this, many people agree with the idea and very fond of it. Up to now, 300 communities in North American, Europe and Asia put this pattern into trial use. And some communities in our country like Nanning, Nanjing and Chongqing are trying to build Time Bank to provide service to elder people.

\section{The Difficulties and Troubles of Popularizing Time Bank}

\section{The Problems of the Organizing and Managing of Time Bank}

The majority of 'Time Banks' putting into trial now are set up by government, and operated and managed by public service organizations which are filled with all parts 
of the society. Because of this, the operation of Time Bank are depending on the supporting degree of the government, the ability of neighborhood committee members in communities and the devotion of the volunteers. Under this operation pattern, funding cannot be guaranteed, the management are slack, there are disadvantages in the standardization of service and operation has low efficiency. All of these put a large rock in the middle of the sustainable developing road of Time Bank.

\section{The Problems of Measuring the Value of Service}

It is service that deposit into the Time Bank. Due to the diversity of services and the differences of difficulty, we can't simply measure it by service time. For instance, can the value of accompany by chatting for an hour be equal to attending to in the hospital for an hour? How to measure it reasonably? We need to find a suitable universal equivalent to make full use of its feature as 'measure of value', which allow us to measure a variety of services and their value equally.

\section{The Problems of 'Universal Saving and Withdrawing'}

Nowadays, a certain communities home and abroad are trying out that pattern. Limited by the space of community unites, the participants are usually local citizens and the depositing and withdrawing services are also limited in the community. Time Bank service cannot be widely spread, for depositing and withdrawing services will be both limited, leading to failures to attract more people to participate in and break the space limitation. If perform 'universal saving and withdrawing' all over the country like Business Bank, participants can deposit services from many places and also withdraw services in a large range .In this way, the influence of Time Bank can be rapidly broadened, appealing to more participants and making sure the honor and the long run of Business Bank.

\section{The Idea of Building Time Bank under Shared Economy}

\section{Analyse about the practicability of Time Bank}

Time Bank Meets the Requirement of Modern Pension Market. The aging problem caused by Family Plan Policy in our country and its consequence -the'4-2-1 family construction', have made the pension problem in our modern society worse and worse. With the traditional pension pattern of children's care becoming no longer practical and institution for old-age care difficult to meet the current needs, how to grow old relieved has become a problem which the olds and their children worry about. Time Bank exactly meets the needs of modern pension, for it allow people to offer service to others at young ages and be provided with the equal services when old and need. This way of saving pension services for ourselves is as reasonable as saving money for pension, which can greatly motivate Time Bank's participants. There are mainly two groups of Time Bank's participants, labor service savers and withdrawers, the savers are also future withdrawers. According to this pattern, young people can use their spare time to provide labor services, contributing and saving services for their parents in case of needs at the same time, the young old can save services up to their condition and schedule flexibly, making full use of themselves to achieve their social value while providing certain guarantee for their pension. Saving and withdrawing of services are both greatly needed by the market.

Shared Economy Makes it Possible to Solve the difficulties of Time Bank. When Time Bank is organized and managed by public service organizations, because 
of the lack of participation of permanent institutions and steady support of fund, it is hard to work out problems of Time Bank such as troubles in management, calculating of serving value and universal saving and withdrawing. The government should introduce corresponding policies of encouragement and privilege and develop Time Bank as pension industry. The way to do this is to encourage enterprises to put money in construction of Time Bank and to operate it in modern company management pattern. In the way of this, the current problems will have well solutions like funding cannot be guaranteed, the organization and management are slack, there are disadvantages in the standardization of service and operation has low efficiency. What's more, based on Internet, Time Bank will be popular all over the country in a tremendous speed, and participants will be widely in and universal saving and withdrawing can be realized in the whole world.

\section{The Constructing Principle of Time Bank under Shared Economy}

Sharing and Cooperation is Aim of Building Time Bank. It is the proposition of the shared economy that everyone shares the same rights, and shares all the social resources for value, and pays or benefit in different ways with each other and share the profits together. It is the aim of sharing and helping each other that Time Bank publicizes. And the main idea of it leads to 'everyone do for me, I do for everyone' and a harmony atmosphere of helping and benefiting each other in the society.

Insist the Uniqueness of Storing and Withdrawing 'Labor Service'. The Time Bank supply $r$ service for the aged. The main idea of it is 'saving and withdrawing of labor service' and it should insist the uniqueness of storing and withdrawing 'labor service' instead of currency. It ought to separate from the pension service which costs money; otherwise we will lose the original intension of 'Time Bank.

Take Count of both Public Welfare and Profitability. To enterprises which spend money in building Time Bank, social responsibility comes to the first, and there must be profits as well, for sustainable input and the perfecting of service depends on profits. To clients who store and withdraw labor time from Time Bank, it is an act of virtue and kindness to serve others. If they benefit from the act at the same time, they will be more enthusiastic to Time Bank.

Keep Trustworthy to Develop the Safety and Justice of Trading. Credits are the life of banks. Time Bank should learn the managing theory of traditional banks which makes keeping trustworthy the foundation of operation. Banks win trust and support of clients based on credits and pledge of clients' withdrawing rights. In addition, Time Bank should calculate labor storing as scientifically and reasonably as possible, and adopt corresponding measures to guarantee clients' safety and justice of trading.

\section{Organization and Management of Time Bank}

The Building of Time Bank. The government introduces corresponding policies of support and privilege with some starting funds. And then bid the building, operating and managing of Time Bank. After generally evaluating bidding plans, enterprise which wins the bidding is ensured. Successful bidders build Time Bank and operate and manage it. Meanwhile, corresponding departments of the country manage and supervise the compliance and legality of its running.

Source of Funds. Time Bank s source of funds consist of government allowance, social contribution and enterprises benefits. Government allowances include some starting fund used for building of Time Bank and allowance at regular intervals based on policies. During the operation, the main source of funds should be relatively stable 
profits coming from increasing income and reduce expenditure in the managing pattern of Internet companies. Besides this, Time Bank can get some of the funds which caring person in society donates as a result of popularizing.

Benefiting Pattern. Time Bank is different from traditional banks, for it can't benefit in the circulation of storing and withdrawing. Profits come from advertising, supplying appreciation service, flow and big data analysis. It can learn from the benefiting pattern of shared-economy enterprises like Didi Taxi.

\section{Designs of Operation of Time Bank}

Clients Management. The clients of Time Bank are in member registration system. Corresponding standards are made to select members by many aspects: basic qualities, health conditions, serving skills, legal compliance, credits, and people meeting the criteria can register to become members of Time Bank. The checking of member qualifications must be very strict so that the security of members can be guaranteed. The service of Time Bank is only for members. Members have some rights at the same time they have their obligations as well. What Time Bank will do for members are to protect their safety by plenty of ways like insuring, locating, visiting during serving, etc. After serving, the scores of others can be get when supplying and accepting service, and the scores will store as the credit evaluation of members. Members of high credits level have priority of getting the service of Time Bank.

The Circulating of Virtual Currency. Based on investigations, count, analyse, classify the projects of service for the aged. The smallest unit of virtual currency will be ensured according to the most basic service project. After comparing other projects with it in many aspects such as labor intensity, technical demand and serving object, the amount of virtual currency of different service projects for the aged will be calculated. As soon as clients successfully register, they will gain fixed amounts of virtual currency for circulating at the beginning. When serving is finished, the accounts of both sides of serving will save or withdraw same sum of virtual currency. The virtual currency on clients' account can be used by them or be gifted to other clients.

Formulate Feasible Service Standard. Service providers of Time Bank are not professionals. Therefore, when they supply service, warm-heartedness and amicability is two most important factors of all. According to existing career standard, Time Bank should try its best to supply better service by formulating different servicing standards which are suitable for its clients and inform them.

Set up Online Platform of Time Bank. Set up Time Bank official website, open up mobile app and build online business hall to ensure the high efficiency of its operation. Most of management and services of Time Bank can carry through on the online platform such as registering, online checking, service and requirement ordering, service evaluating, saving or withdrawing of virtual currency.

\section{Online and Offline Process Diagram of Time Bank}

According to the above-mentioned idea, the online and offline process diagram is shown in Figure. 1 


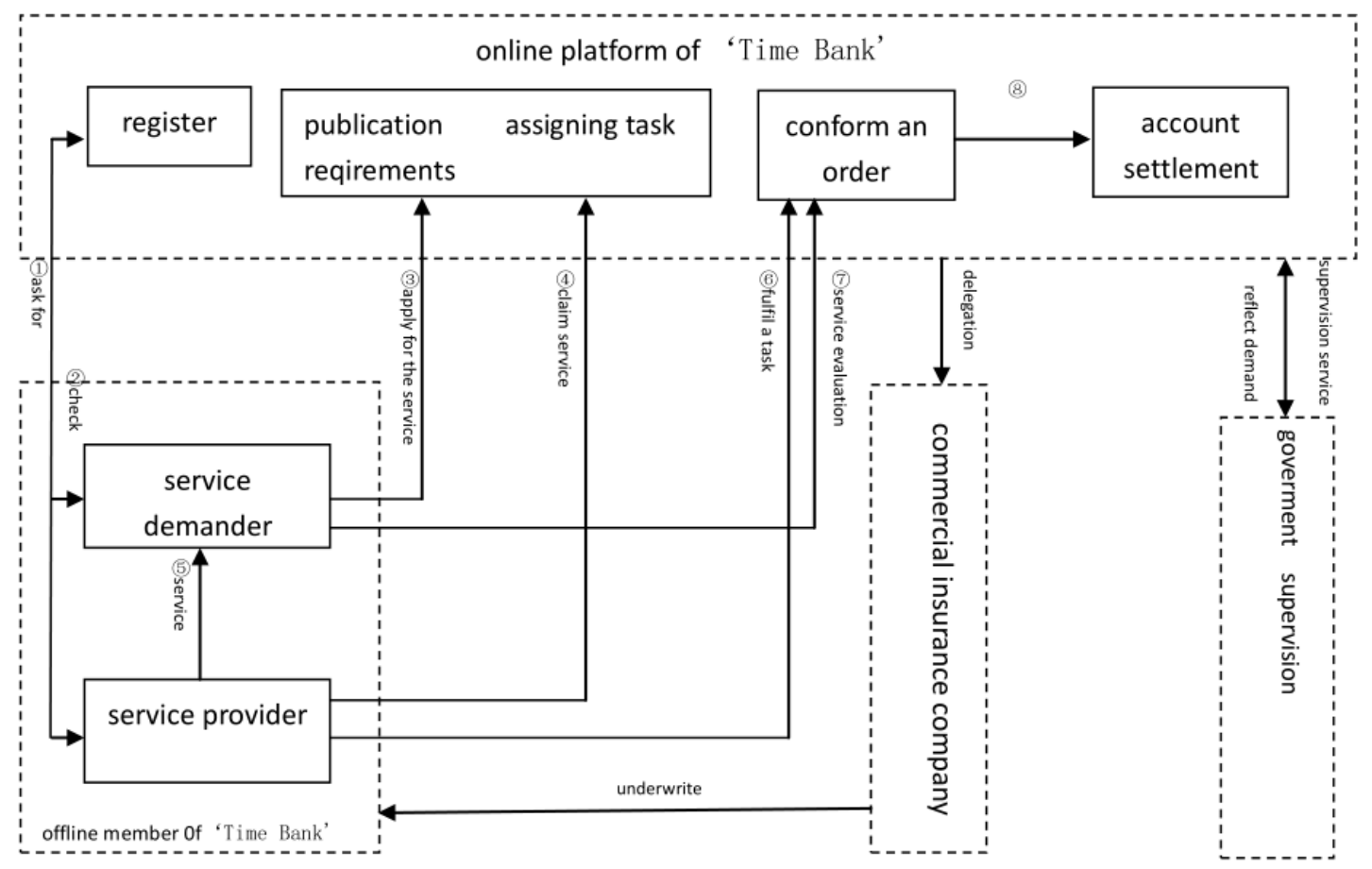

Figure 1. Online and offline process diagram of 'Time Bank'

\section{Conclusions}

As the idea of Time Bank is coming out for a period of time, people begin to accept it. There are a few domestic and international cases of 'Time Banks' in recent years. Because of the unsolvable problems in the process of specific implementing, Time Bank is hard to be popular widely. Today, these problems can be solved in pace with popularizing of Internet, developing of information technology and disseminating of shared economic. Thus, it is feasible to construct 'Time Banks' at the present stage in our country and will bring positive society value. On this basis of this, the article structured abecedarian design of Time Bank by analyzing how to solve the difficulties, however, the concrete measures need to be further refined, discussed and inspected by practice.

\section{References}

[1] Information on http://www.nstimebank.com

[2] MEN Yang. REN Sa and BIAN Ruhan, The exploration of new pattern on community endowment, Productivity research. 2016(7)84-86.

[3] CHU Weiwei. WU Fei, The study of community service for home care of elderly by Time Bank, symposium of CCP , Beijing, China Architecture \& Building Press, 2015

[4] WU Yaqin. SUN Yaonan, The empirical research of city community service on new economic normality, Business economy. 2017 (1)67-70. 